\title{
Urticaceae-feeders from the family Tischeriidae: descriptions of two new species and new genus Paratischeria gen. nov.
}

\author{
Jonas R. Stonis ${ }^{1^{*}}$, \\ Arūnas Diškus ${ }^{1}$, \\ Brigita Paulavičiūtè ${ }^{2}$ \\ Alex K. Monro 3 \\ ${ }^{1}$ Lithuanian University of Educational \\ Sciences and Baltic-American \\ Biotaxonomy Institute, Studentu St. 39, \\ Vilnius LT-08106, Lithuania \\ ${ }^{2}$ Tadas Ivanauskas Zoological Museum, \\ Laisvès Ave. 106, \\ Kaunas LT-44253, Lithuania \\ ${ }^{3}$ Royal Botanic Gardens, \\ Kew, Richmond, Surrey TW9 3AE, \\ London, United Kingdom
}

We describe a new genus Paratischeria Diškus \& Stonis, gen. nov. and present the first observations of Urticaceae-feeding Tischeriidae species in South America and two new Urticaceaefeeding species (Paratischeria fasciata sp. nov. and P. ferruginea Diškus \& Stonis, sp. nov. from the Andes of Bolivia and Ecuador). Together with the African P. urticicolella (Ghesquière) (comb. nov.) from Congo, they are attributed to the newly designated ferruginea species group.

Keywords: The Andes, leaf-mines, new genus, new species, Paratischeria, Phenax Wedd., South America, Tischeriidae, Urticaceae

\section{INTRODUCTION}

The Tischeriidae represents the relatively small family of Lepidoptera. The most recent detailed family review was provided by Diškus, Puplesis, 2003. Among the most distinctive diagnostic features of the family is the long length of male antennal sensillae (Fig. 67); females possess much shorter sensillae, therefore, female antennae appear bare in ventral view. Among other characters that also have diagnostic importance for family recognition are the following: (1) frontal tuft (Fig. 26) projecting over triangular (or trapezoid) face smoothly covered with scales; (2) sensillae trichodea with

\footnotetext{
* Corresponding author. E-mail: stonis@leu.lt
}

strongly recurved bases (Fig. 67); (3) strongly enlarged 3rd antennal segment (Fig. 67); (4) strongly narrowed phallus (Figs. 8, 33, 45), usually bifurcated or with spines at apex; (5) dark, short, strongly thickened, stout peg setae on female ovipositor (usually visible even without dissection) (Fig. 29); (6) specific rod-like or plate-like projections of modified 8th and 9th sternites in female genitalia collectively referred as prela (Fig. 31 ).

Literature on Tischeriidae is still rather scarce (for the history of research on the family investigation and a literature review, see Puplesis, Diškus, 2003). Since then several papers have been published, notably: Landry, Roque-Albelo, 2004; Puplesis et al., 2004; Mey, 2004, 2010; Puplesis, Diškus, 2005; Diškus, Stonis, 2006, 2012, 2015; 
Stonis, Diškus, 2007, 2008; Lees, Stonis, 2007; Stonis et al., 2008, 2014, 2016; Hua, Cai, 2009; van Nieukerken, 2010; Navickaite et al., 2011; Diškus et al., 2014; Kobayashi et al., 2016.

Tischeriidae are trophically associated with plants belonging to rosid and asterid I core eudicot angiosperm families Fagaceae (Fagales), Rosaceae, Rhamnaceae (Rosales), Malvaceae (Tilioideae, Sterculioideae, Malvales), and Asteraceae (Asterales). A few represantatives of Tischeriidae have also been recorded on plants from the Combretaceae (Myrtales), Euphorbiaceae (Malpighiales), Ericaceae, Symplocaceae (Ericales), Anacardiaceae (Sapindales), Theaceae (Ericales), Hypericaceae (Malpighiales), Betulaceae (Fagales), and Apocynaceae (Gentianales) (Diškus, Puplesis, 2003a, 2003b; Kobayashi et al., 2016). In temperate regions the family is strongly associated with plants from the Rosaceae and Fagaceae, in the Americas also with Malvaceae and Asteraceae. However, only a single record of the Urticaceaefeeding species was previously known from equatorial Africa (Puplesis, Diškus, 2005), and no records from the Americas.

In this paper, we review our recent findings in South America together with the previous record of the Urticaceae-feeding species from Congo, equatorial Africa (Fig. 1). We illustrate the African species and describe two new Tischeriidae species from the Andes: one trophically associated with Phenax hirtus, other feeding on unidentified Urticaceae plant but not Phenax.

Host plant Urticaceae is a medium-sized family comprising ca 2,500 species and 50 genera of woody shrubs, succulent herbs, trees and vines that are found on all of the world's continents with the exception of Antarctica. A short characterization of Urticaceae will be provided in our other paper on the Urticaceae-feeding Nepticulidae (Stonis et al., submitted).

\section{MATERIALS AND METHODS}

Descriptions of new species are based on the material deposited in the collection of the Zoological Museum, Natural History Museum of Denmark in Copenhagen, Denmark.
Collecting methods and protocols for species identification and description are outlined in Puplesis, Diškus (2003) and Diškus, Stonis (2012). After maceration of the abdomen in $10 \%$ $\mathrm{KOH}$ and subsequent cleaning, male genital capsules were removed from the abdomen and mounted ventral side uppermost. The phallus was removed and mounted in Euparal separately but on the same genitalia slide. Abdominal pelts and female genitalia were stained with Chlorazol Black (Direct Black 38/Azo Black) (for a detailed method's description see Stonis et al., 2014).

Permanent slides were photographed and studied using a Leica DM2500 microscope and a Leica DFC420 digital camera. The descriptive terminology of morphological structures follows Puplesis, Diškus (2003), except for the term "aedeagus" that is referred here as "phallus", and the term "cilia" that is referred here as "fringe".

For DNA extraction we used specimens which were stored in $96 \%$ ethanol. Total genomic DNA was extracted from head or thorax using a Nucleospin Tissue Kit (MacheryNagel, Düren, Germany) according to the protocol of the manufacturer.

Amplification of a 577-bp fragment of the mtDNA region was performed using mitochondrial cytochrome c oxidase subunit I gene (COI): LCO1490 (5'-GGT CAA CAA ATC ATA AAG ATA TTG G-3') and HCO2198 (5'-TAA ACT TCA GGG TGA CCA AAA AAT CA-3') (Folmer et al., 1994; Herbert et al., 2003a, 2003b). PCR were performed in $25 \mu$ l volumes including: $2 \mu \mathrm{L}$ DNA, $2 \mu \mathrm{L}$ of each primer (MBI Fermentas, Lithuania), $0.5 \mu \mathrm{L}$ of Amplitaq DNA polymerase $(5 \mathrm{U} / \mu \mathrm{l}), 2.5 \mu \mathrm{l} 25 \mathrm{mM} \mathrm{MgCl}_{2}$, $2.5 \mu \mathrm{L} 10 \mathrm{X}$ Buffer (Fermentas) and $1 \mu \mathrm{L} 10 \mathrm{mM}$ dNTP (Fermentas) and water.

PCR were carried out in an Eppendorf Mastercycler gradient, 5331 (Germany). Cycling parameters were an initial denaturation step at $94{ }^{\circ} \mathrm{C}$ for $2 \mathrm{~min}$, followed by $94^{\circ} \mathrm{C}$ for $30 \mathrm{~s}$, $50{ }^{\circ} \mathrm{C}$ for $45 \mathrm{~s}$, and $72{ }^{\circ} \mathrm{C}$ for $1 \mathrm{~min}$. This cycle was repeated 35 times, followed by $4 \mathrm{~min}$ of extension at $72{ }^{\circ} \mathrm{C}$. PCR products were visualized on $1.5 \%$ agarose gel stained with ethidium bromide and UV light photographs of the gels with DNA bands were taken using "Herolab" 
transluminator (Germany). The positive bands of the expected size range were excised from the gel. DNA was extracted using the GeneJet Gel Extraction kit (Fermentas, Lithuania). Amplicons were then sequenced in both directions on an automated sequencer, ABI 3130xl (Applied Biosystems, USA).

Electropherograms were checked by eye for poor base calls and sequence quality and then sequences were edited and aligned using the ClustalW (Thomson et al., 1994) algorithm in MEGA v.7.0.21 (Kumar et al. 2015). Phylogenetic relationships among control region haplotypes were reconstructed using the neighbour-joining (NJ) method (Saitou, Nei, 1987). $\mathrm{NJ}$ analysis was performed using the Kimura-2 paratemeter correction model (Kimura, 1980) by bootstrapping with 1000 replicates.

Partial fragment of Cytochrome oxidase I (COI) gene were amplified in 21 Tischeriidae specimens. Amplified fragment produced a 577-bp sequence which corresponded to COI gene sequence position 2239-2944.

The partial nucleotide sequences of the Tischeriidae species COI gene were added to the GenBank database. Sequences accession numbers are presented in Table.

Institutional abbreviations used in the text of the current paper: MRAC - Museé Royal de l'Afrique Centrale, Tervuren, Belgium; ZMUC - Zoological Museum, University of Copenhagen, Denmark.

Table 1. GenBank accession numbers of examined specimens of Tischeriidae

\begin{tabular}{|c|c|}
\hline Examined specimens & Accession number GenBank \\
\hline Coptotriche marginea (1) (Haworth, 1828) & HM244382 \\
\hline Coptotriche marginea (2) (Haworth, 1828) & HM244379 \\
\hline Coptotriche marginea (3) (Haworth, 1828) & HM244380 \\
\hline Coptotriche marginea (4) (Haworth, 1828) & HM244381 \\
\hline Tischeria ekebladella (1) (Bjerkander, 1795) & HM244384 \\
\hline Tischeria ekebladella (2) (Bjerkander, 1795) & HM244385 \\
\hline Tischeria ekebladella (3) (Bjerkander, 1795) & HM244383 \\
\hline Tischeria dodonea (1) Stainton, 1858 & HM244386 \\
\hline Tischeria dodonea (3) Stainton, 1858 & HM244387 \\
\hline Astrotischeria sp. 4848 & HM244389 \\
\hline “Astrotischeria” sp. 4877, Paratischeria sp. & HM244393 \\
\hline $\begin{array}{c}\text { “Astrotischeria” sp. 4894, Paratischeria ferruginea } \\
\text { Diškus \& Stonis, sp. nov. }\end{array}$ & HM244395 \\
\hline $\begin{array}{c}\text { "Astrotischeria" sp. 4909.1, Paratischeria neotropicana } \\
\text { (Diškus \& Stonis, 2015) }\end{array}$ & HM244391 \\
\hline $\begin{array}{c}\text { "Astrotischeria" sp. 4909.2, Paratischeria neotropicana } \\
\text { (Diškus \& Stonis, 2015) }\end{array}$ & HM244392 \\
\hline Astrotischeria sp. 4910 & HM244390 \\
\hline $\begin{array}{c}\text { “Astrotischeria” sp. 4936, Paratischeria ferruginea } \\
\text { Diškus \& Stonis, sp. nov. }\end{array}$ & HM244394 \\
\hline $\begin{array}{c}\text { “Astrotischeria" sp. 4937, Paratischeria neotropicana } \\
\text { (Diškus \& Stonis, 2015) }\end{array}$ & HM244396 \\
\hline “Astrotischeria" sp. 4939, Paratischeria sp. & HM244398 \\
\hline Astrotischeria sp. 4944.2 & HM244397 \\
\hline Astrotischeria sp. 4957.1 & HM244399 \\
\hline Astrotischeria sp. 49572 & HM244400 \\
\hline
\end{tabular}




\section{RESULTS}

Taxonomy of the Urticaceae-feeding Tischeriidae

Three currently known Urticaceae-feeding Tischeriidae, including one Afrotropical and two Neotropical species, together with some American Malvaceae and Asteraceae-feeding species, belong to a new genus, Paratischeria Diškus \& Stonis, gen. nov., which is described below.

Genus Paratisheria Diškus \& Stonis, gen. nov. Type species: Paratischeria ferruginea Diškus \& Stonis, sp. nov.

Diagnosis. In the male genitalia, the new genus differs from Astrotischeria in the undivided, usually narrow valva (divided in Astrotischeria), long undivided uncus (usually short and divided in Astrotischeria), and the strongly though variously developed anellus (Figs. 4853); from Coptotriche it differs in the slender valva, well developed anellus with lateral papillae and setae (Figs. 48-53), also in the absence of transtilla, absence of spines on the diaphragma, larger vinculum, and differently shaped phallus (not tulip-shaped as in Coptotriche); from Tischeria it differs in the absence of juxta, presence of strongly developed anellus (absent in Tischeria), and usually larger vinculum. Also see Figs. 73, 74.

Head (Figs. 54-67). Scape with a pecten. 3rd antennal segment greatly enlarged.

Wing venation (Figs. 68-70). Greatly reduced, similar to Astrotischeria (Fig. 71). In the forewing, vein Sc almost reaching middle of wing; $\mathrm{R}$ with five short radial branches terminating on costa; radial cell reduced; $M$ with two short branches distally and with base absent; vein $\mathrm{Cu}$ single, very long and straight; $2 \mathrm{~A}$ well-developed, but simple; in hindwing, Sc very short; $\mathrm{R}, \mathrm{M}$ and $\mathrm{Cu}$ expressed only in distal half (if not entirely reduced), vein A single or represented by two short veins.

Abdomen (Fig. 72). Male with a short anal tuft of piliform scales.

Male genitalia. Uncus with long lateral lobes (Fig. 38). Socii not thickened, similar to those in Astrotischeria. Tegumen large, with strongly sclerotized anterior processes; posteriorly not extending into a lobed pseuduncus. Diaphragma smooth or with membranous wringles but without spines. Valva relatively slender, undivided. Transtilla absent. Anellus always well-developed, slightly thickened laterally and with three or four pairs of papillae and setae, sometimes additionally with a dorsal sclerite (pseudotranstilla) (Figs. 48-53). Juxta absent. Vinculum moderately large to very large, anteriorly either broadly rounded or gradually narrowed. Phallus long and distinctly bifurcate in apical half or apical third (Figs. 33, 45).

Female genitalia. Ovipositor lobes large (Figs. 29, 31); the second pair of lobes very small. Anterior and posterior apophyses supplemented with three pairs of shorter rod-like and plate-like sclerites (prela) (Fig. 31). Vestibulum membranous or hardened but antrum absent. Corpus bursae slender, as long as anterior apophyses or longer, usually without pectination; signa absent. Ductus spermathecae membranous, slender, with a few to many convolutions.

Biology. Larvae produce bloth-like mines (Figs. 11-19) in leaves of plants from Malvaceae, Urticaceae, and Asteraceae.

Distribution. Known from the New World (the Americas) and equatorial Africa. There are many species from Central and South America which have already been dissected, identified but still undescribed (Stonis et al., in prep).

Etymology. The name combines Tischeria (a name of the type genus of the family) and Greek prefix para (at or to one side of, side by side, beyond).

\section{The ferruginea species group}

Designated here for the first time for the $\mathrm{Pa}$ ratischeria species feeding on Urticaceae and possessing a dorsal sclerite (pseudotranstilla) in the male genitalia.

Diagnostics: forewing dark brown to brown (not sparsely speckled as is usual in other $\mathrm{Pa}$ ratischeria or Astrotischeria), with $\operatorname{spot}(\mathrm{s})$ (Figs. 5, 26), fascia (Fig. 5), or without spots or fascia, uniform. In male genitalia, phallus deeply divided in distal half (Figs. 7, 8, 32-34, 
45); valva moderately slender (but wider than in many other Paratischeria species) or strongly widened in basal half (Fig. 36); basal process of valva long (Figs. 6, 39, 44); uncus with two long (Fig. 38) to very long lobes (Fig. 46); anellus with a dorsal sclerite (pseudotranstilla) (Figs. 42-44); vinculum large but smaller than in most of other Paratischeria, triangular (Fig. 35) or distally broadly rounded (Figs. 6, 44).

Currently the group comprises three equatorial or subequatorial species (two from the Andes of Ecuador and Bolivia), one from Africa (Congo); all species are trophically associated with plants from Urticaceae (Phenax and Fleurya).

Paratischeria fasciata Diškus \& Stonis, sp. nov. Type material. Holotype: $\hat{\sigma}$, BOLIVIA: Nor Yungas Province, Coroico, 16 $11^{\prime} 39^{\prime \prime}$, $67^{\circ} 43^{\prime} 21^{\prime \prime} \mathrm{W}$, elevation $1880 \mathrm{~m}$, mining larva on unidentified Urticaceae plant 25.iv.2014, ex pupa v.2014, A. Diškus, genitalia slide no. AD868 ${ }^{\lambda}$ (ZMUC). Paratype: 1 ${ }^{\AA}$, same label data as holotype (ZMUC).

Diagnosis. Externally, the new species differs from all other known tischeriids by a distinctive fascia of the forewing. In male genitalia, a specific shape of phallus and dorsally developed anellus distinguish Paratischeria fasciata sp. nov. from all other Tischeriidae species; the Urticaceae host plant, shared with three other related species, also makes this taxon distinctive.

Male (Figs. 4, 5). Forewing length 3.0$3.2 \mathrm{~mm}$; wingspan $6.5-6.8 \mathrm{~mm}$. Head: face smoothly scaled, palpi and face grey-brown or olive brown, very glossy and with some golden shine and purple iridescence; frontal tuft greybrown to olive brown, smooth, not erected

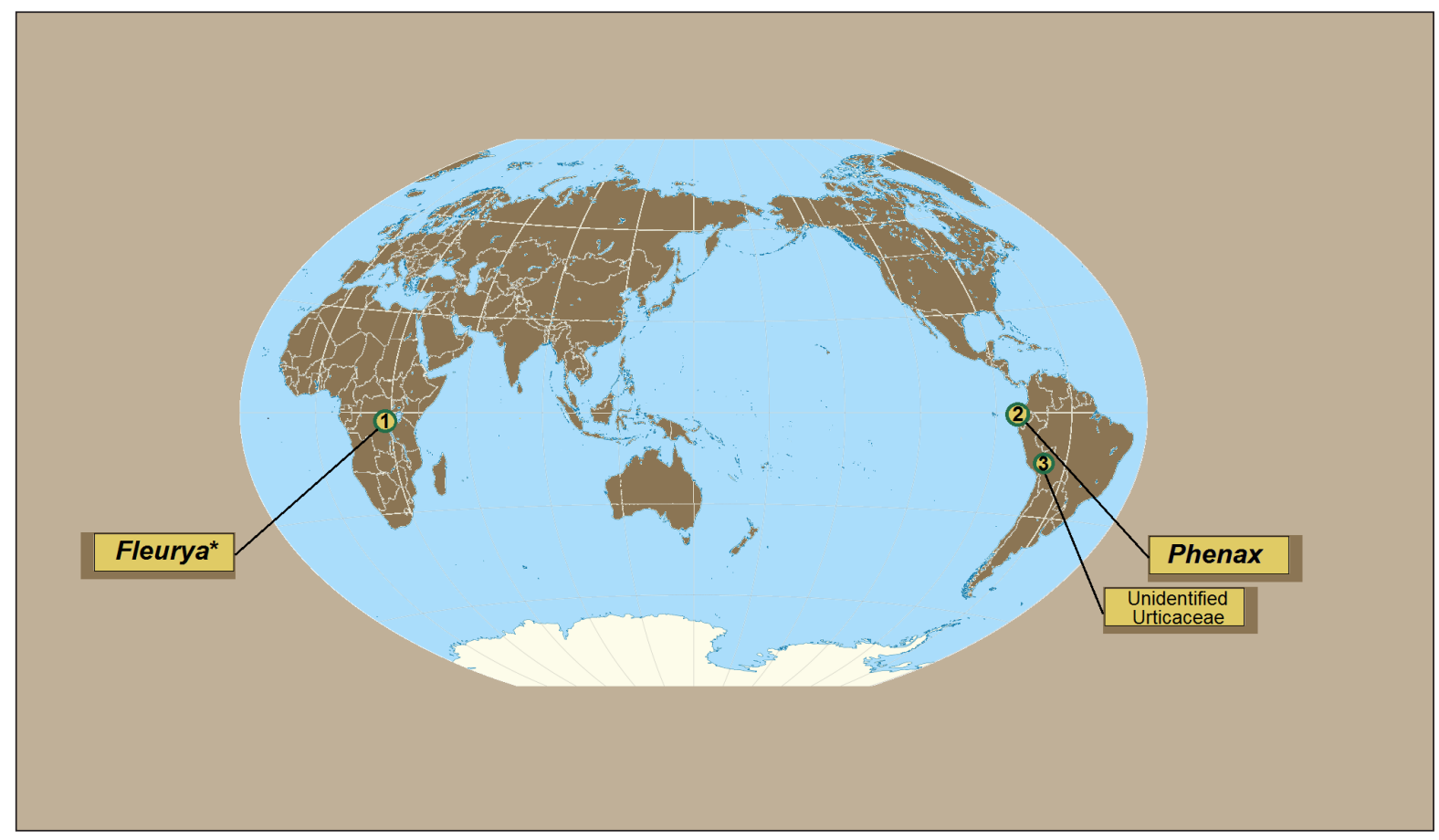

Fig. 1. Currently known records of Tischeriidae trophically associated with the genera of Urticaceae: $1-P a$ ratischeria urticicolella (Ghesquière, 1940) on Fleurya podocarpa Wedd. from Congo (see Puplesis, Diškus, 2005); 2 - P. ferruginea Diškus \& Stonis, sp. nov. on Phenax hirtus (Sw.) Wedd. from Pichincha Province, Ecuador; 3 - P. fasciata Diškus \& Stonis, sp. nov. on unidentified Urticaceae plant, Coroico, Bolivia;

* - earlier, by Ghesquière, 1940, the host plant was reported as Laportea podocarpa Wedd., however, the genus Laportea has been split and the host plant is attributed now to Fleurya. Fleurya podocarpa Wedd. is placed as a synonym of ovalifolia, however, such combination of ovalifolia with Fleurya has not been published. 


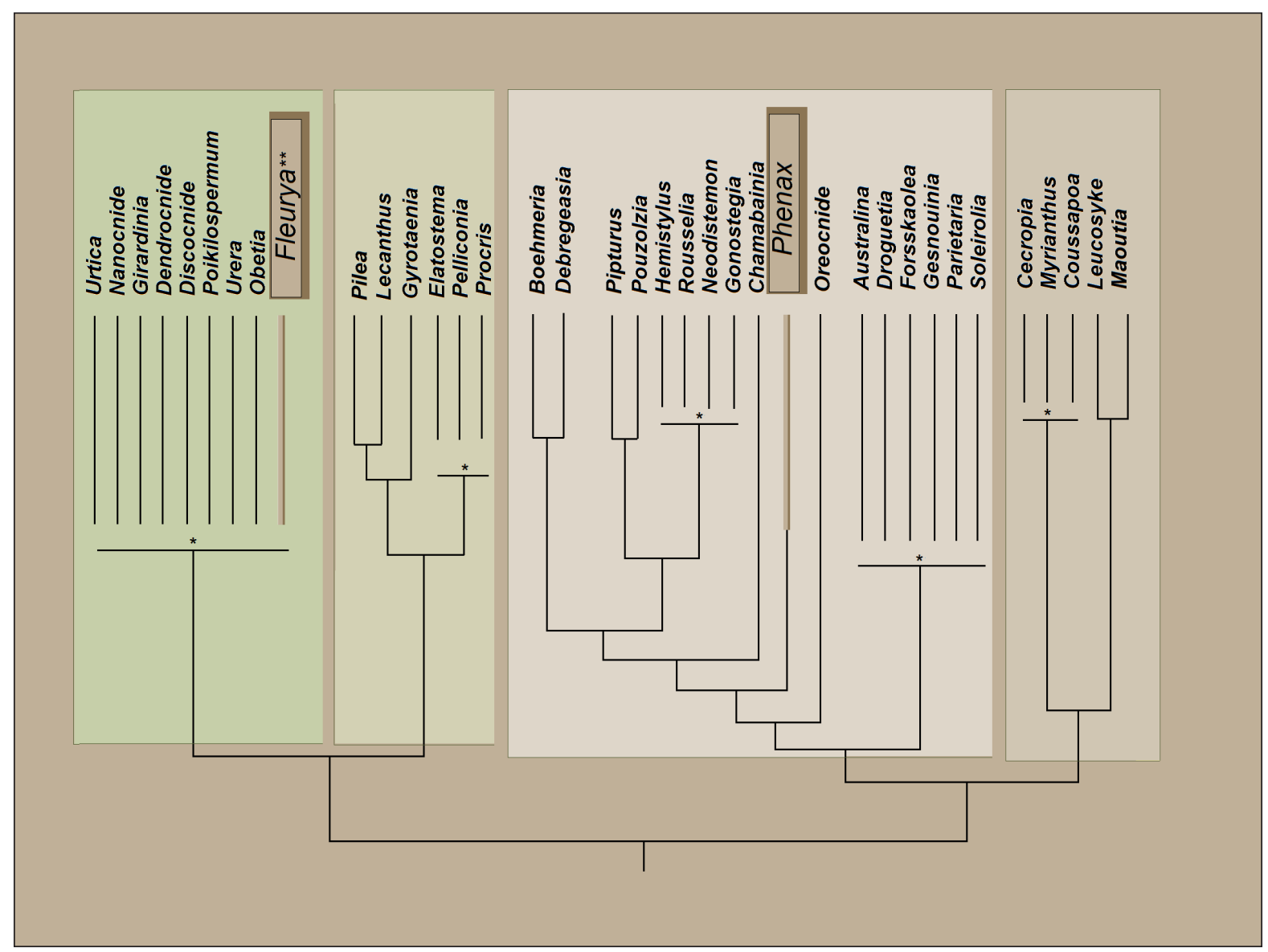

Fig. 2. Urticaceae clades engaged by leaf-mining Tischeriidae (simplified phylogeny after Wu et al., 2013. Note: this is not an ultrametric tree)

* - for detailed relationships of the clades, see Wu et al., 2013

** - originally, the host plant was reported as belonging to the genus Laportea (see Ghesquière, 1940), however, the genus Laportea has been split and the host plant is attributed now to genus Fleurya.

but overlapping over face; antenna slightly longer than half the length of forewing, greybrown, golden glossy, with long hair-like sensillae trichodea sticking out. Thorax and tegula black-brown with strong golden gloss and some purple iridescence. Forewing blackbrown with some golden gloss and purple and blue iridescence; median fascia and basal spot yellow orange, very distinctive; fringe dark brown with some golden gloss; underside of forewing brown-black, without spots except small irregular scaleless patch at the base. Hindwing dark brown on upper side, brownblack on underside, without androconia or spots except small irregular scaleless patch at the base on underside; its fringe blackish brown. Legs grey, glossy. Abdomen blackbrown on upper side, dark grey, glossy on underside; genital segments dark grey-brown to grey, distally white; anal tufts short, blackish brown.

Female. Unknown.

Male genitalia (Figs. 6-10). Capsule about $455 \mu \mathrm{m}$ long. Uncus with two long lateral lobes. Valva about $350 \mu \mathrm{m}$ long, not divided, without processes (except the basal one); transtilla absent. Anellus thickened laterally and with setae (Figs. 6, 51), dorsally with a specific plate-like sclerite (pseudotranstilla) (Figs. 6, 43). Vinculum rather short, rounded distally. Phallus (Figs. 7, 8) $455 \mu \mathrm{m}$ long, with three pairs of large carinae. 


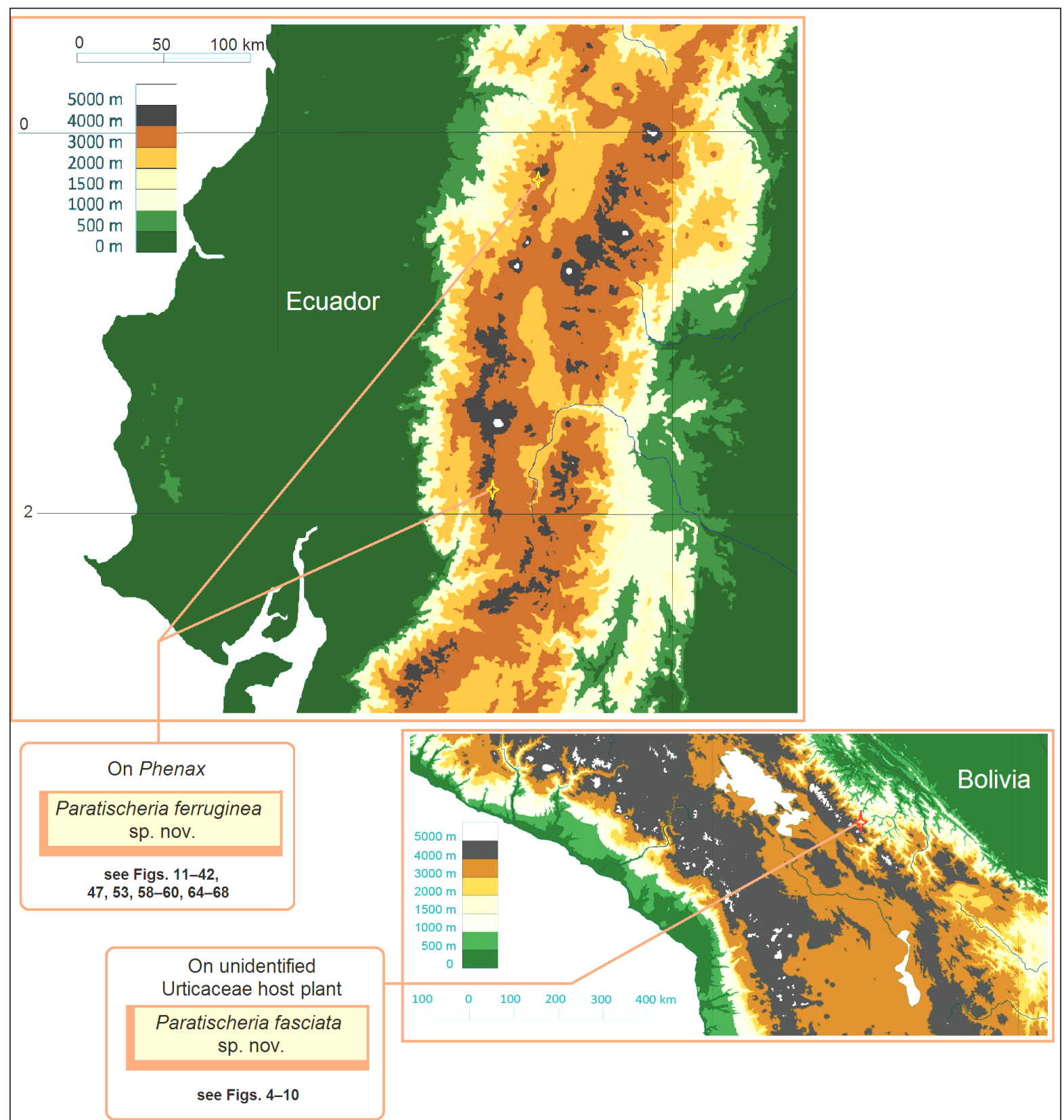

Fig. 3. Current records of Urticaceae-feeding Tischeriidae from South America

Bionomics. Host plant belongs to Urticaceae (species and genus unidentified; host-plant sample neither preserved nor documented). Larvae mine in leaves in April. A leaf-mine similar to those illustrated in Figs. 11-19). Exit slit on the upper side of the leaf. According to the "Formula of Determining of Abundance and Occurrence of Leaf-Miners" (see Diškus, Stonis 2012: 52-54), Paratischeria fasciata is a rare species: sparse mining of the new species was observed in a single locality of the Bolivian Andes.

Distribution (Figs. 1, 3). This species occurs on the eastern slopes of the Bolivian Andes in tropical montane forests at altitudes ca. $1880 \mathrm{~m}$.

Etymology. The species name is derived from the Latin fascia/fasciata (a band, fascia/ with fascia) in reference to the distinctive fascia on the forewing, so unusual among the Tischeriidae. 


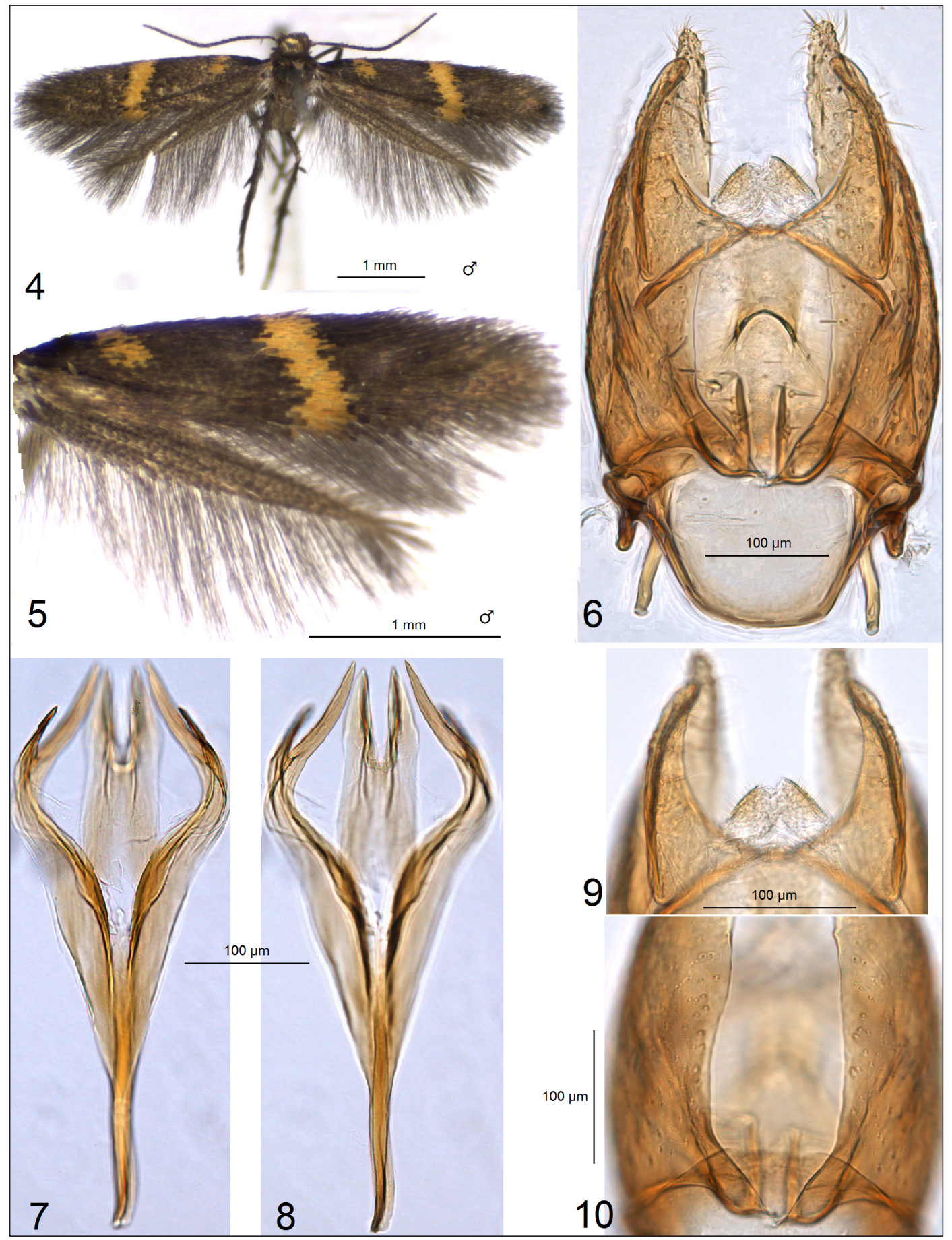

Figs. 4-10. Paratischeria fasciata Diškus \& Stonis, sp. nov.: 4, 5 - male adult, holotype; 6, genitalia slide no. AD868, capsule with phallus removed; 7, 8 - same, phallus; 9 - same, uncus and socii; 10 - same, basal part of valvae (ZMUC)

Paratischeria ferruginea Diškus \& Stonis, sp. nov.

Type material. Holotype: $\hat{\jmath}$, ECUADOR: Pichincha Province, $11 \mathrm{~km} \mathrm{NW}$ Alóag, $0^{\circ} 26^{\prime} 45^{\prime \prime} \mathrm{S}, 78^{\circ} 37^{\prime} 34^{\prime \prime} \mathrm{W}$, elevation $3090 \mathrm{~m}$, mining larvae on Phenax hirtus (Urticaceae) 20.xi.2007, field card no. 4936, A. Diškus, genitalia slide no. AD775 $\widehat{ }$ (ZMUC). Paratypes: $4 \hat{O}$ (including a genitalia and head slide of one adult in the pupal skin, with no pinned 

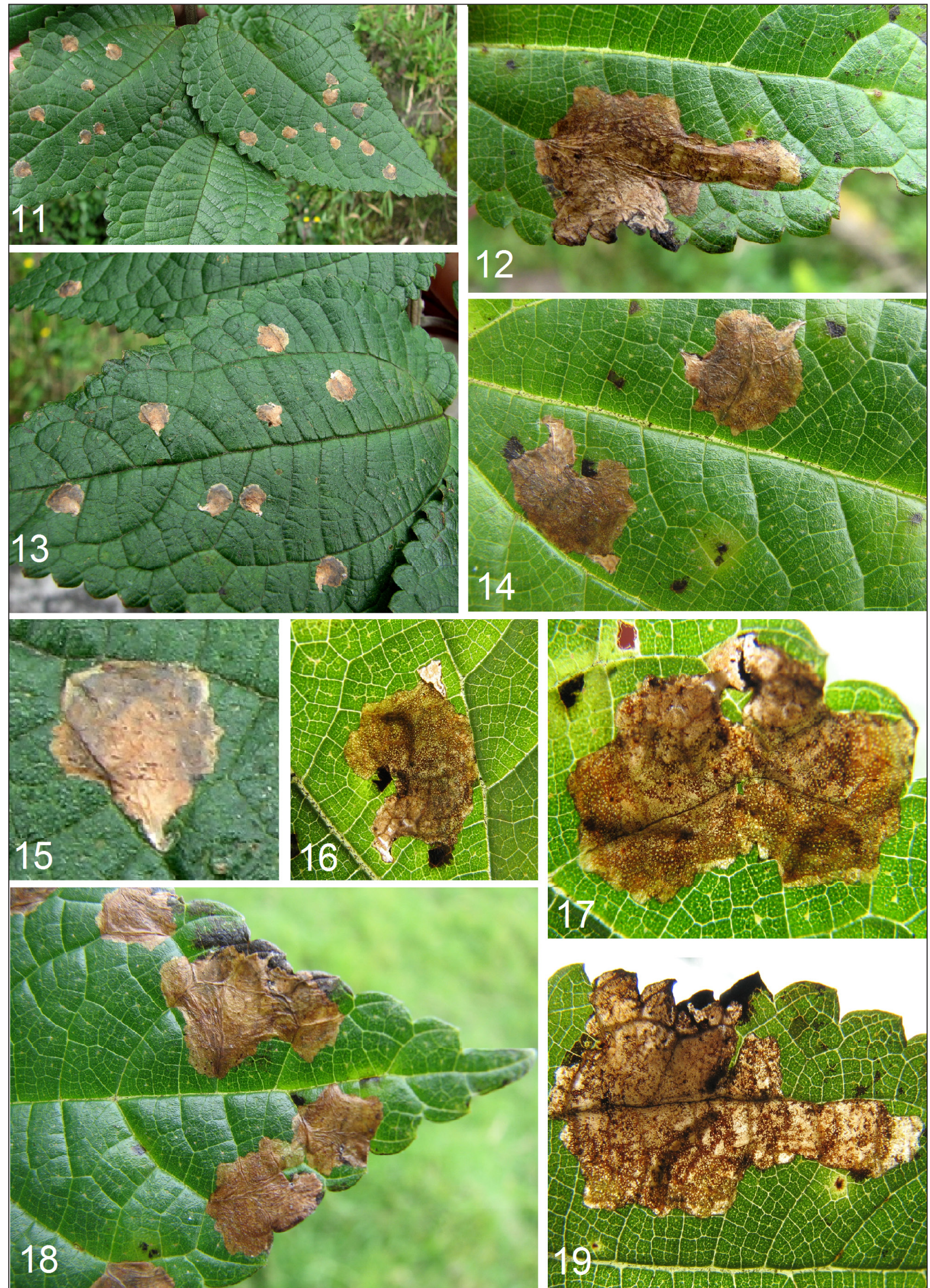

Figs. 11-19. Leaf-mines of Paratischeria ferruginea Diškus \& Stonis, sp. nov. on Phenax hirtus, Ecuador, Pichincha Province, 11 km NW Alóag, 0²6’45”S, 78³7’34”W, elevation 3090 m 
specimen preserved), 5 , same label data as holotype, slide nos. AD839 (genitalia), AD866 ${ }^{\lambda}$ (genitalia), AD865 (head), AD863

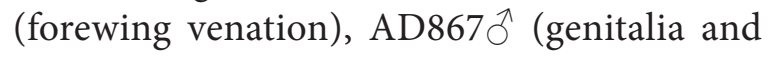

head; both from adult in the pupal skin with no pinned specimen preserved), AD840우 (genitalia) (ZMUC); 1 $\hat{0}, 1$ \%, same locality as holotype, mining larvae on Phenax hirtus

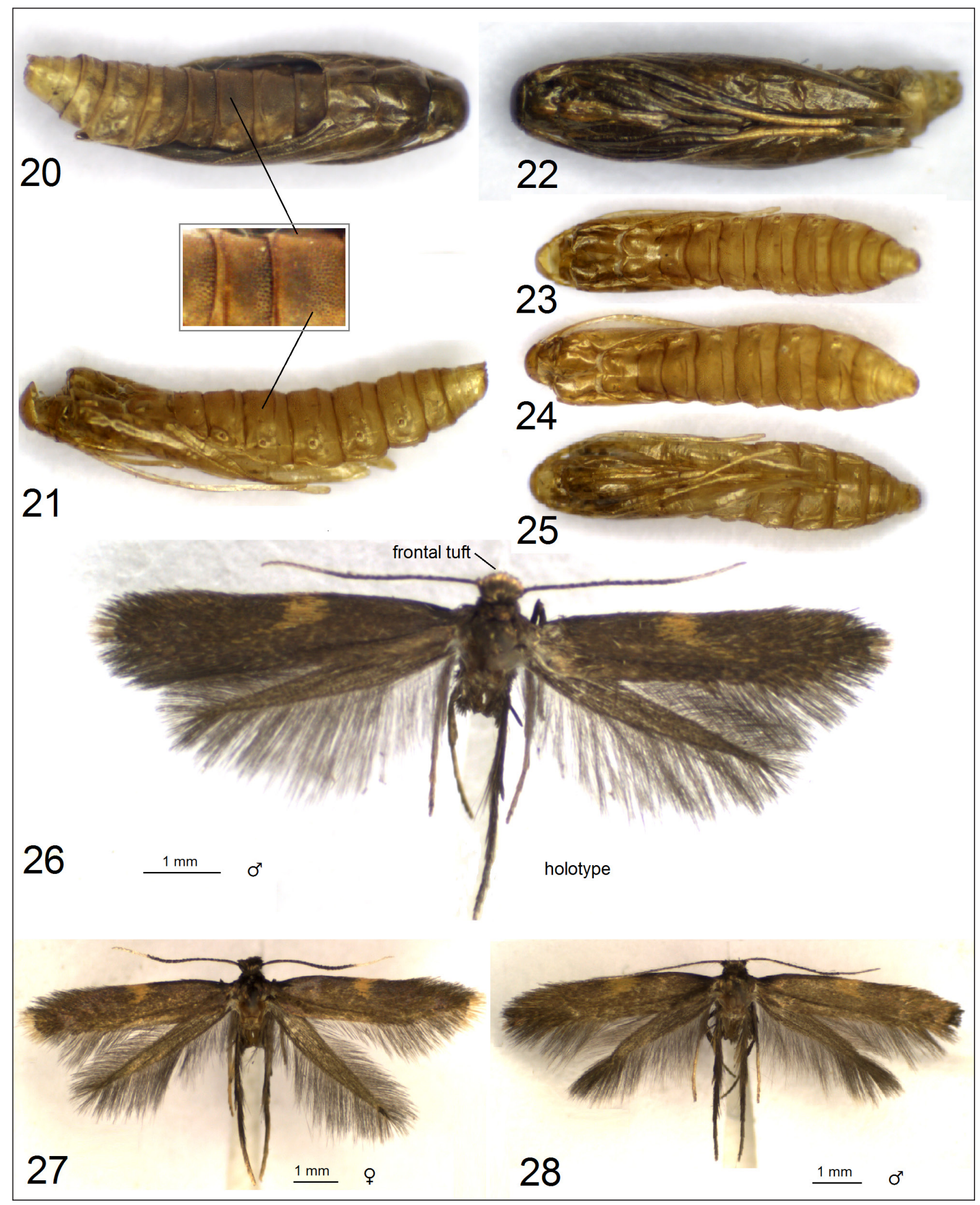

Figs. 20-28. Paratischeria ferruginea Diškus \& Stonis, sp. nov.: 20, 22 - pupae; $21,23-25$ - pupal exuviae; 26 - adult male, holotype; 27 - adult female, paratype AD840; 28 - adult male, paratype AD841 (ZMUC) 
24.ii.2007, field card no. 4894, Diškus and Stonis, slide no. AD841 $\widehat{O}^{\wedge}$ (dissected genitalia) (ZMUC); 1 त, 1 क, Loja Province, $5 \mathrm{~km}$ SW Saraguro, Washapamba Forest Reserve, $3^{\circ} 39^{\prime} 43^{\prime \prime} \mathrm{S}, 7^{\circ} 16^{\prime} 9^{\prime \prime} \mathrm{W}$, elevation $2940 \mathrm{~m}$, mining larvae on Phenax sp. (probably Ph. hirtus or closely related species) 25.i.2017, field card no. 5233, A. Diškus (ZMUC).

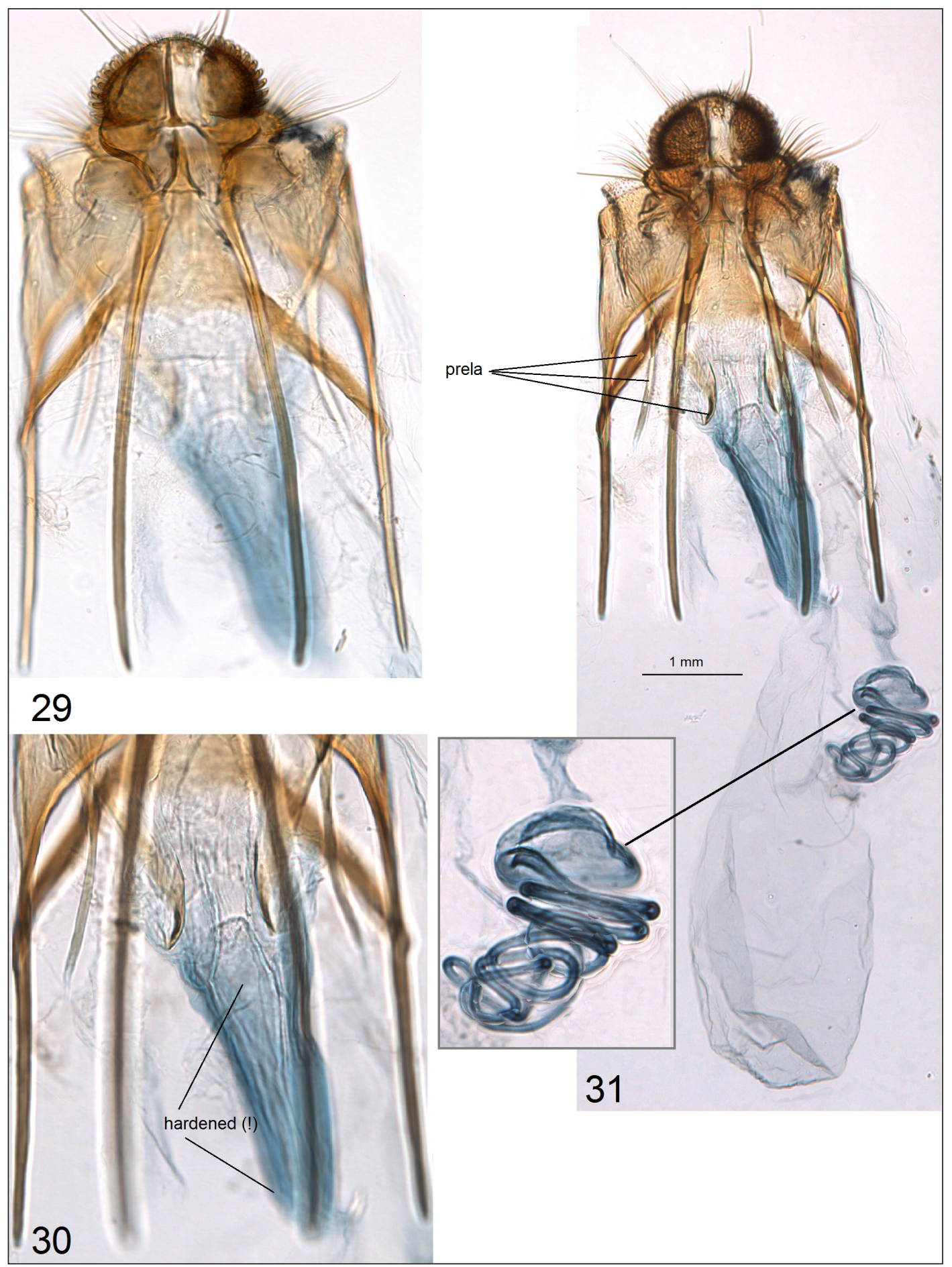

Figs. 29-31. Female genitalia of Paratischeria ferruginea Diškus \& Stonis, sp. nov., paratype, genitalia slide no. AD840: 29 - apophyses and ovipositor; 30 - vestibulum; 31 - general view of genitalia (ZMUC) 


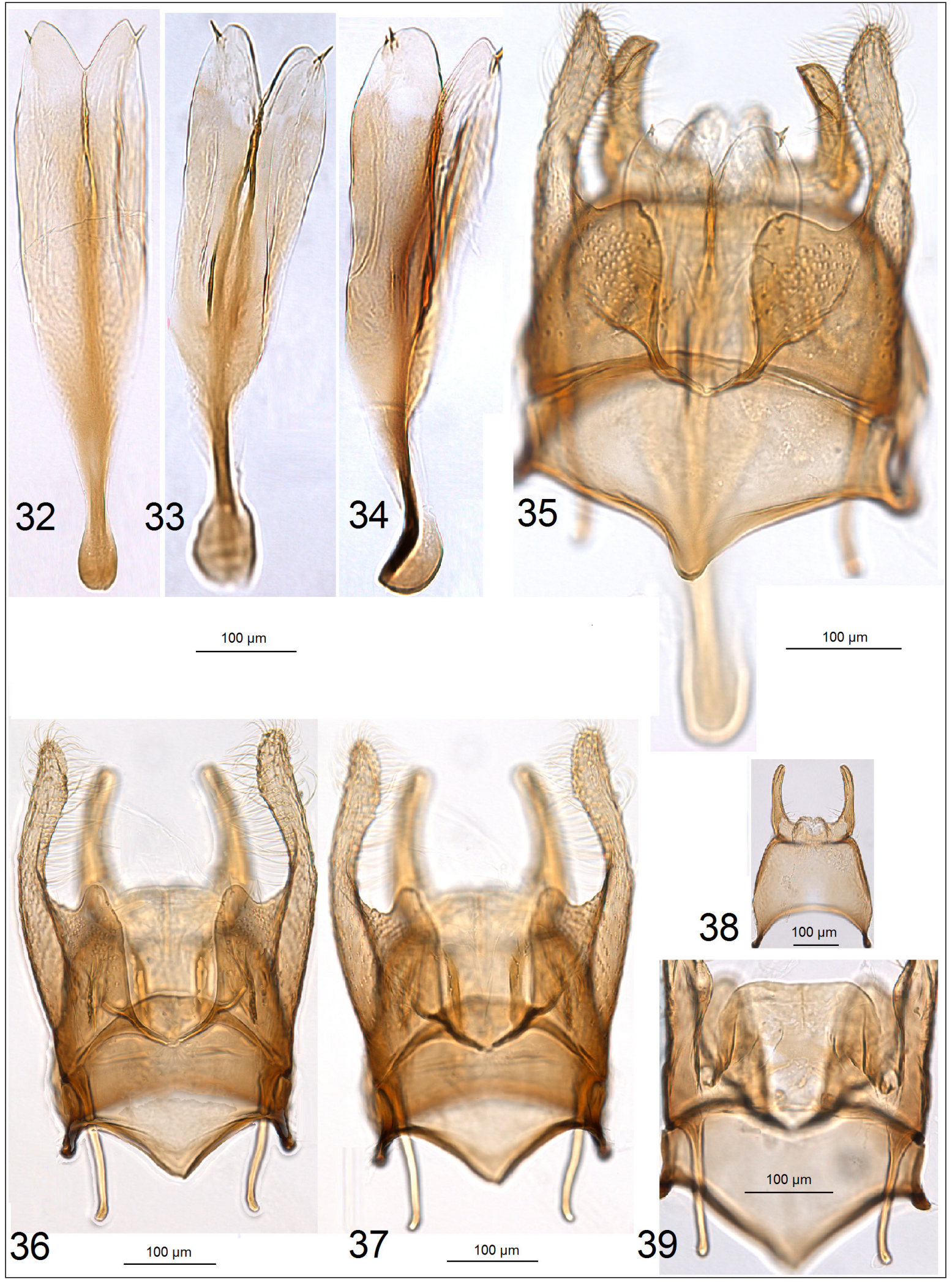

Figs. 32-39. Male genitalia of Paratischeria ferruginea Diškus \& Stonis, sp. nov.: 32, phallus, holotype, genitalia slide AD775; 33 - same, paratype, genitalia slide no. AD867; 34 - same, paratype, genitalia slide no. AD841; 35 - general view, AD866; 36-37 - capsule, holotype, AD775; 38 - uncus and tegumen, paratype, AD839; 39 - dorsal sclerite of anellus (pseudotranstilla), paratype, AD839 (ZMUC) 


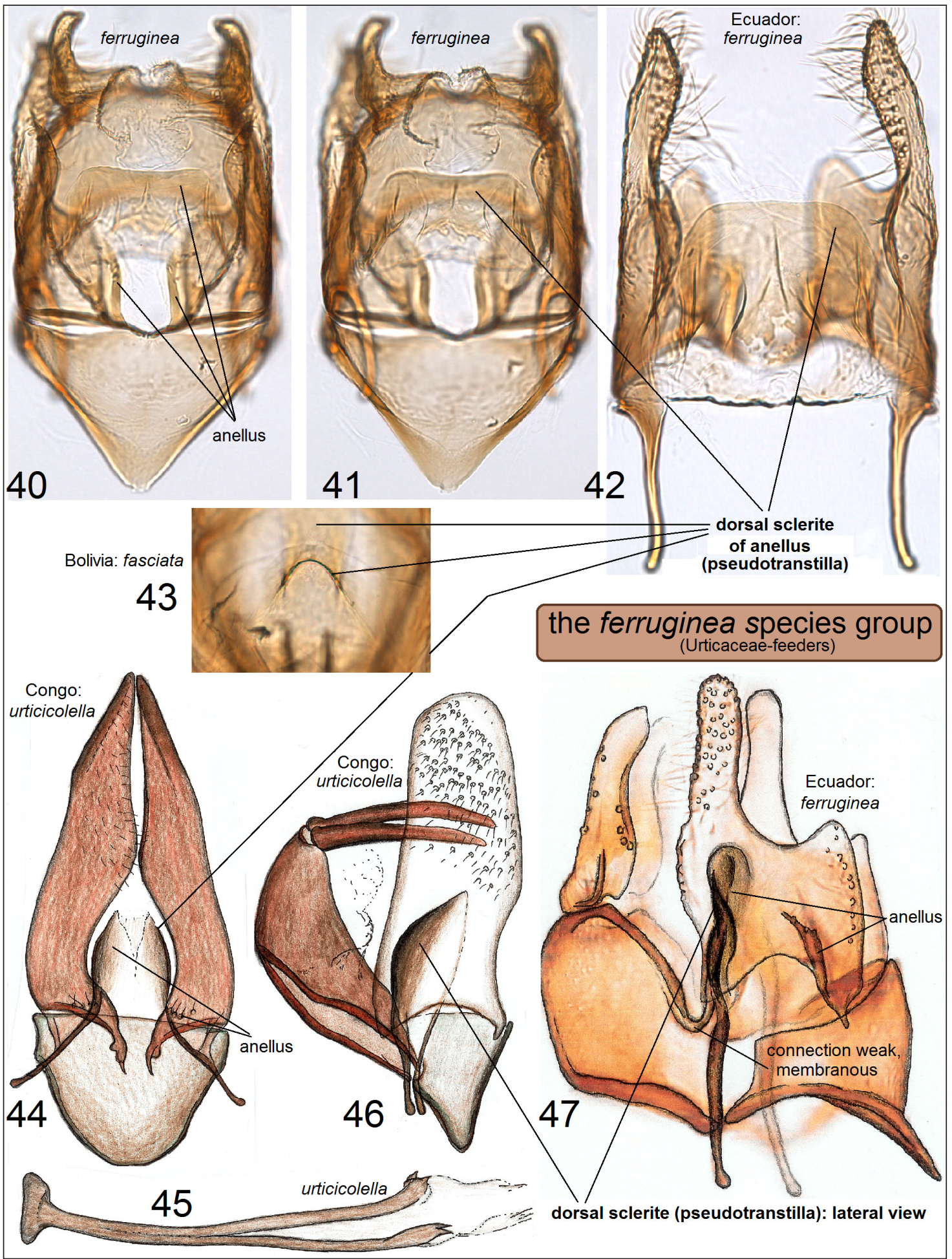

Figs. 40-47. Male genitalia of the ferruginea group: 40, 41 - capsule of Paratischeria ferruginea Diškus \& Stonis, sp. nov., paratype, genitalia slide no. AD867; 42, same, genitalia slide no. AD841; 43 - dorsal sclerite of $P$. fasciata Diškus \& Stonis, sp. nov., holotype, genitalia slide no. AD868 (ZMUC); 44 - ventral view of capsule of $P$. urticicolella (Ghesquière, 1940) (comb. nov.), holotype, genitalia slide no. AD091 (MRAC); 45 - same, phallus; 46 - same, lateral view of capsule, slide no. AD091 (MRAC); 47 - lateral view of capsule of $P$. ferruginea Diškus \& Stonis, sp. nov., paratype, genitalia slide no. AD841 (ZMUC) 


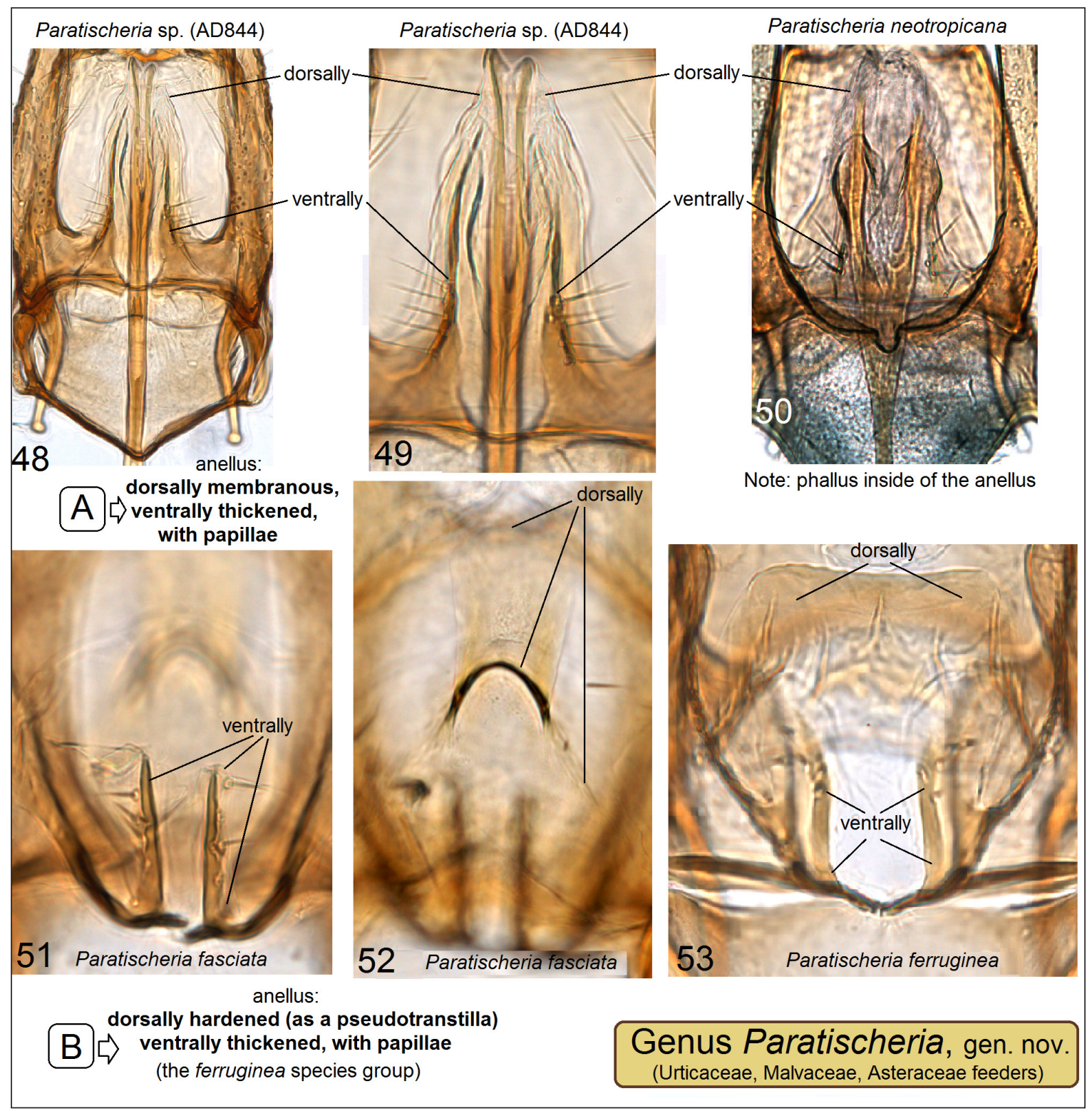

Figs. 48-53. Anellus of Paratischeria Diškus \& Stonis, gen. nov.: 48, 49 - P. sp., genitalia slide AD844; 50 - P. neotropicana (Diškus \& Stonis, 2015), comb. nov., genitalia slide AD861; 51, 52 - P. fasciata Diškus \& Stonis, sp. nov., genitalia slide AD868; 53 - P. ferruginea Diškus \& Stonis, sp. nov., genitalia slide AD867 (ZMUC)

Diagnosis. Externally, the new species differs from all other known tischeriids by a unique pattern of forewing with one distinctive ochrebeige spot. In male genitalia, a specific shape of bilobed valva and dorsally developed anellus distinguish Paratischeria ferruginea sp. nov. from all other Tischeriidae species; the host plant Phenax hirtus also makes this species distinctive.

Male (Figs. 26, 28). Forewing length 4.3$5.0 \mathrm{~mm}$; wingspan 9.1-10.7 mm. Head: face dark grey-brown with golden gloss and purple iridescence; palpi and proboscis ochre; frontal tuft grey-brown with golden gloss and little or strong purple iridescence; collar grey-brown with golden gloss and sometimes with strong purple iridescence; antenna significantly longer than half the length of forewing, grey-brown with some golden gloss on upper side, paler on underside, with rather indistinctive hairlike sensillae trichodea. Thorax and tegula 


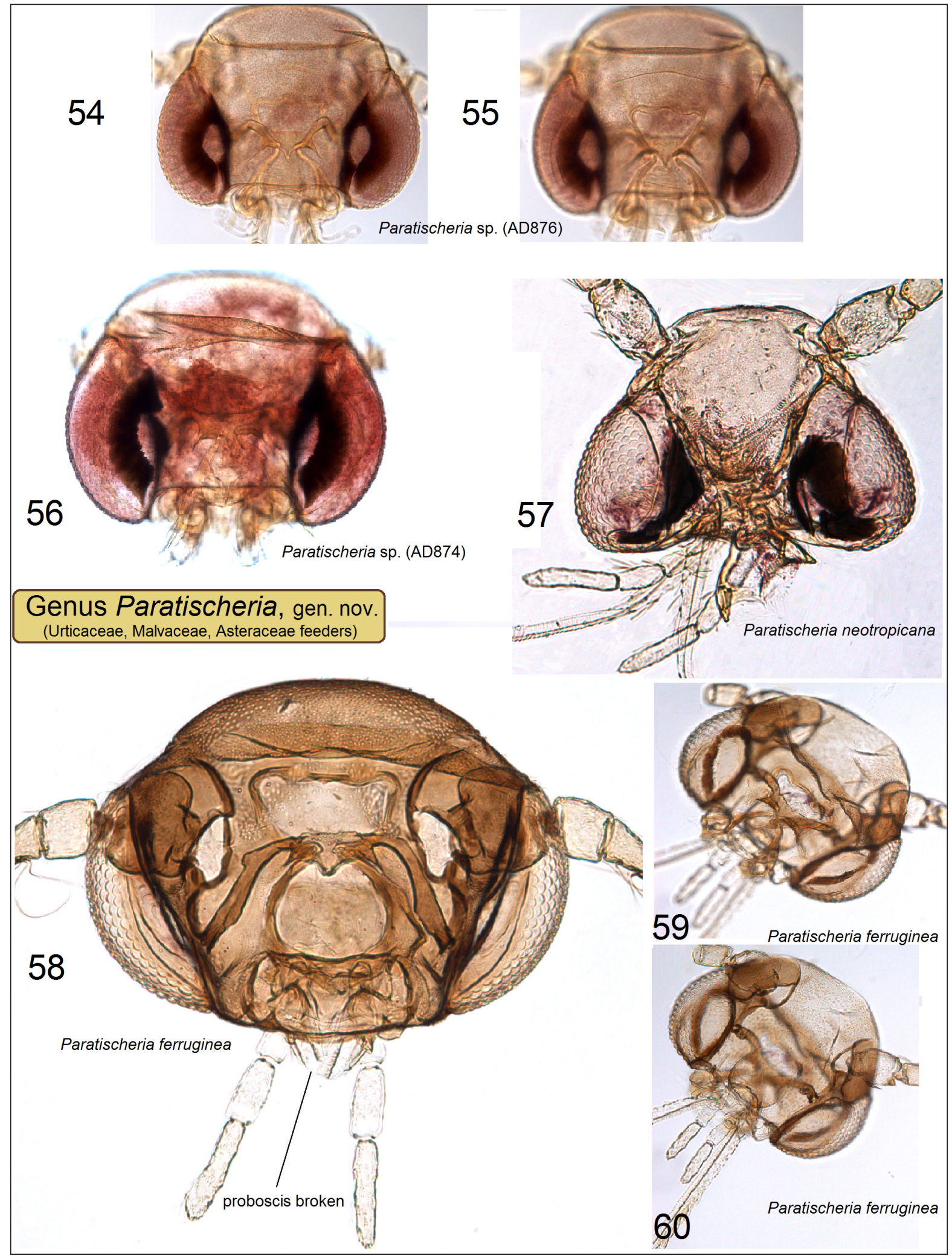

Figs. 54-60. Descaled head of Paratischeria Diškus \& Stonis, gen. nov.: 54, 55 - P. sp., slide no. AD876ㅇ [5116]; 56 - P. sp., slide no. AD874 957 - P. neotropicana (Diškus \& Stonis, 2015), comb. nov., slide no. AD861; 58 - P. ferruginea Diškus \& Stonis, sp. nov., paratype, slide no. AD865; 59, 60, same, paratype, dissected from adult in pupal skin, slide no. AD867 (ZMUC) 


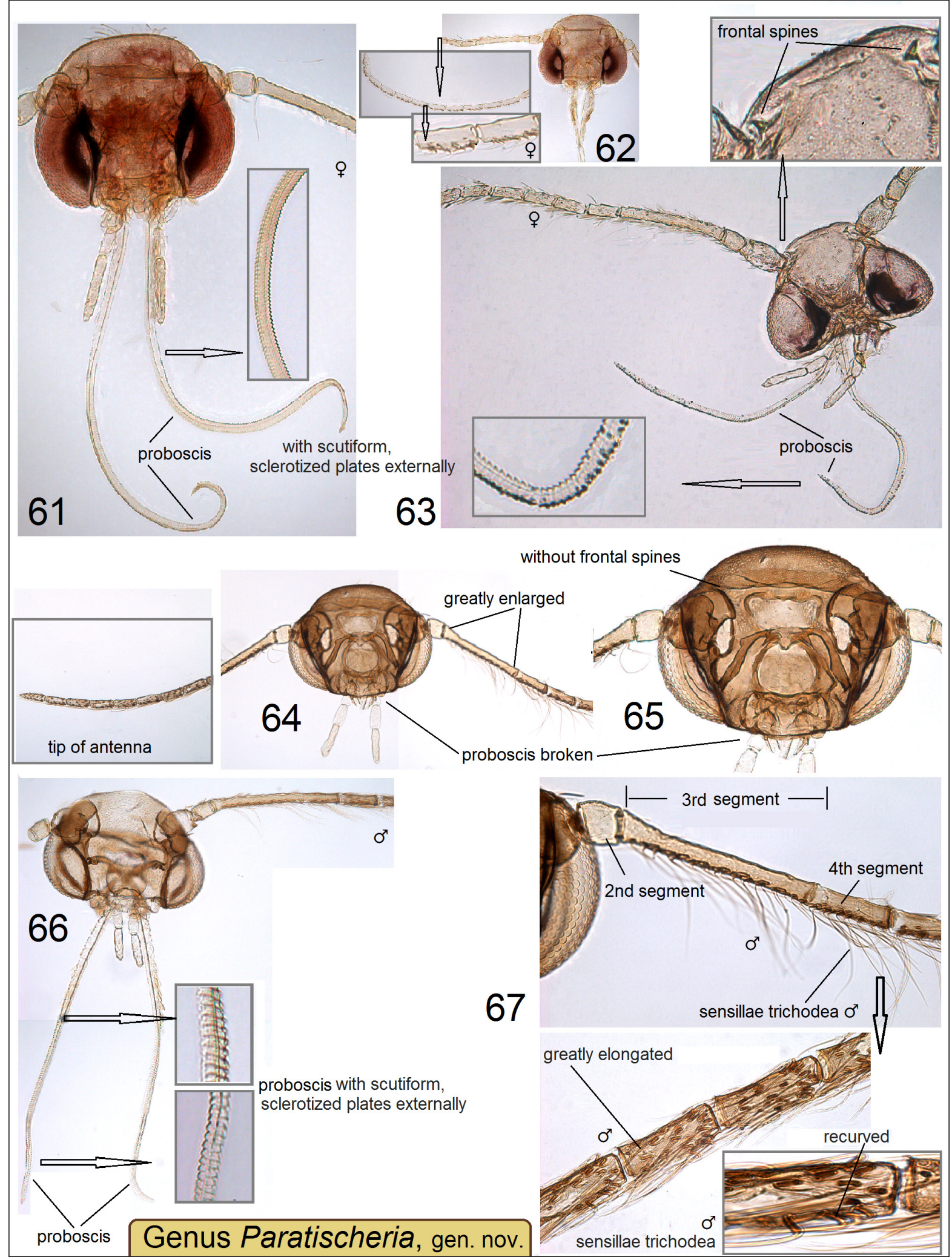

Figs. 61-67. Descaled head of Paratischeria Diškus \& Stonis, gen. nov.: 61 - P. sp., slide no. AD874우 [5109]; 62 - P. sp., slide no. AD876 [5116]; 63 - P. neotropicana (Diškus \& Stonis, 2015), comb. nov., slide no. AD861; 64, 65 - P. ferruginea Diškus \& Stonis, sp. nov., paratype, slide no. AD865; 66, same, paratype, slide no. AD867; 67 - same, paratype, slide no. AD865 (ZMUC) 
dark grey-brown to black-brown, with golden gloss and strong purple iridescence. Forewing dark grey-brown with some purple and blue iridescence; median spot along costal margin, ochre beige (ferruginous), usually large and very distinctive, occasionally small and indistinctive; fringe grey-brown with some golden gloss (particularly prominent at costa), distinctly ochre at the very apex of forewing; underside of forewing dark grey-brown, without spots except small, irregular scaleless patch at the base. Hindwing glossy, grey-brown to olive grey on the upper side, grey-brown on underside, without androconia or spots except very small irregular scaleless patch at the base on underside; fringe grey-brown. Legs glossy, grey-brown, except femur of middlegs which distinctly ochre beige (ferruginous); tibia of hindlegs with a large tuft of ochre yellow piliform scales. Abdomen dark brown with some golden gloss on the upper side, bright yellow ochre to orange yellow and glossy on underside; genital segments dark grey-brown; anal tufts indistinctive.
Female (Fig. 27). Forewing length 4.0$4.5 \mathrm{~mm}$; wingspan 8.7-9.7 mm. Antenna shorter, sensillae trichodea indistinctive, 8-12 distal segments greyish white. Legs dark grey on the upper side, mostly ochre beige on underside. Abdomen dark brown on the upper side, bright yellow ochre yellow and glossy on underside. Otherwise as in male.

Male genitalia (Figs. 32-42, 47, 53). Capsule about 420-470 $\mu \mathrm{m}$ long, $305 \mu \mathrm{m}$ wide. Uncus with two long lateral lobes. Valva about 320$375 \mu \mathrm{m}$ long, slender in distal half, with wide lobe basally; transtilla absent. Anellus slightly thickened and with setae laterally (Fig. 40), dorsally with a specific plate-like sclerite (pseudotranstilla) (Figs. 41, 42, 47). Vinculum triangular. Phallus (Figs. 32-34) 500-570 $\mu \mathrm{m}$ long, distally $140-150 \mu \mathrm{m}$ wide, distinctly bilobed; each lobe with a tiny spine.

Female genitalia (Figs. 29-31). Ovipositor clothed in short, stout and darker, modified setae which we refer to as 'peg setae' (Fig. 29). Second pair of lobes, lateral and anterior to the ovipositor lobes, are three times smaller, bearing

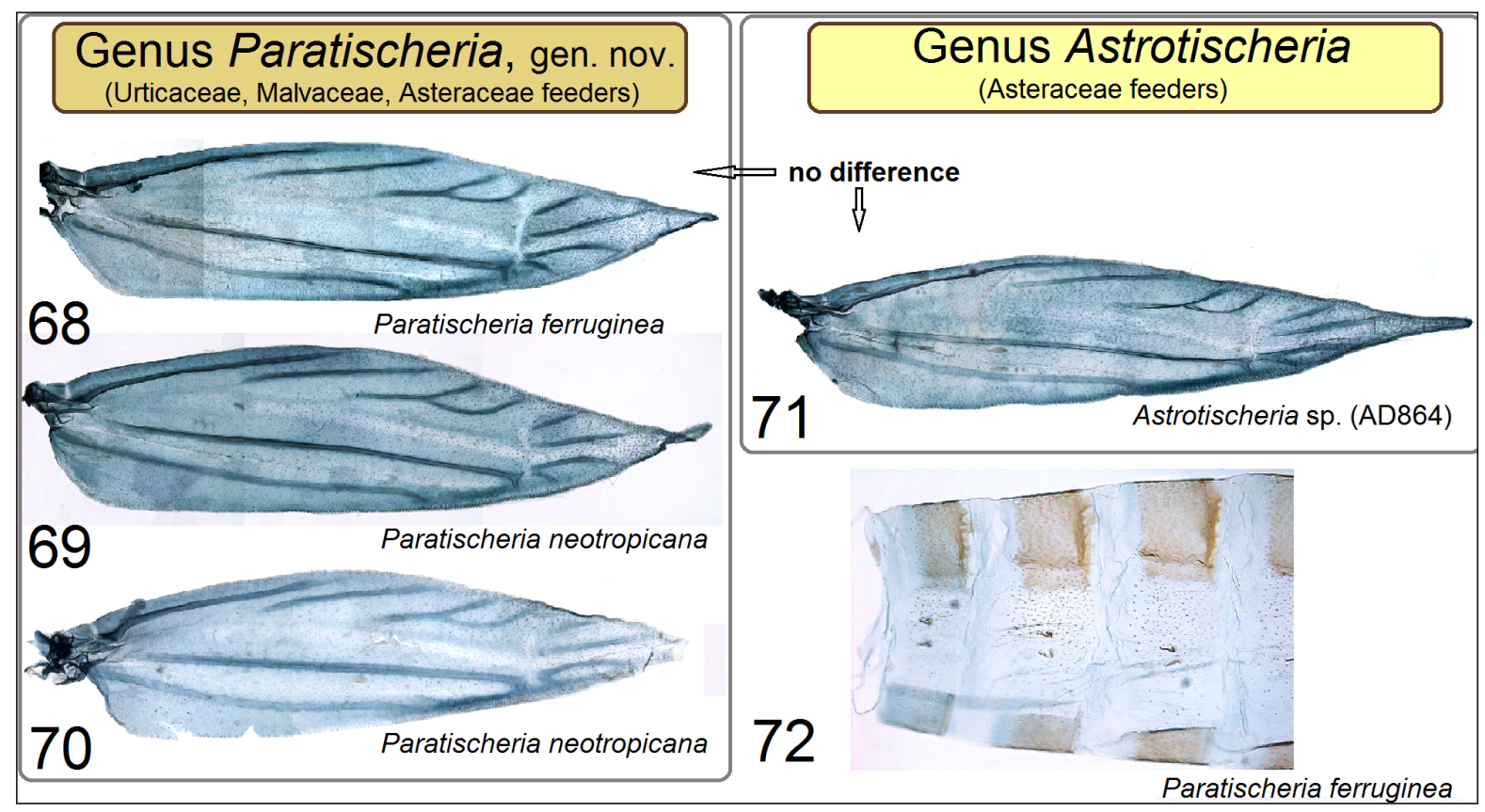

Figs. 68-72. Forewing venation and abdominal pelt: 68, forewing venation, Paratischeria ferruginea Diškus \& Stonis, sp. nov., slide no. AD863; 69 - same, P. neotropicana (Diškus \& Stonis, 2015), comb. nov., slide no. AD862; 70 - same, slide no. AD861; 71 - same, Astrotischeria sp., slide no. AD864; 72 - fragment of abdominal pelt, lateral view, P. ferruginea Diškus \& Stonis, sp. nov., slide AD841 (ZMUC) 


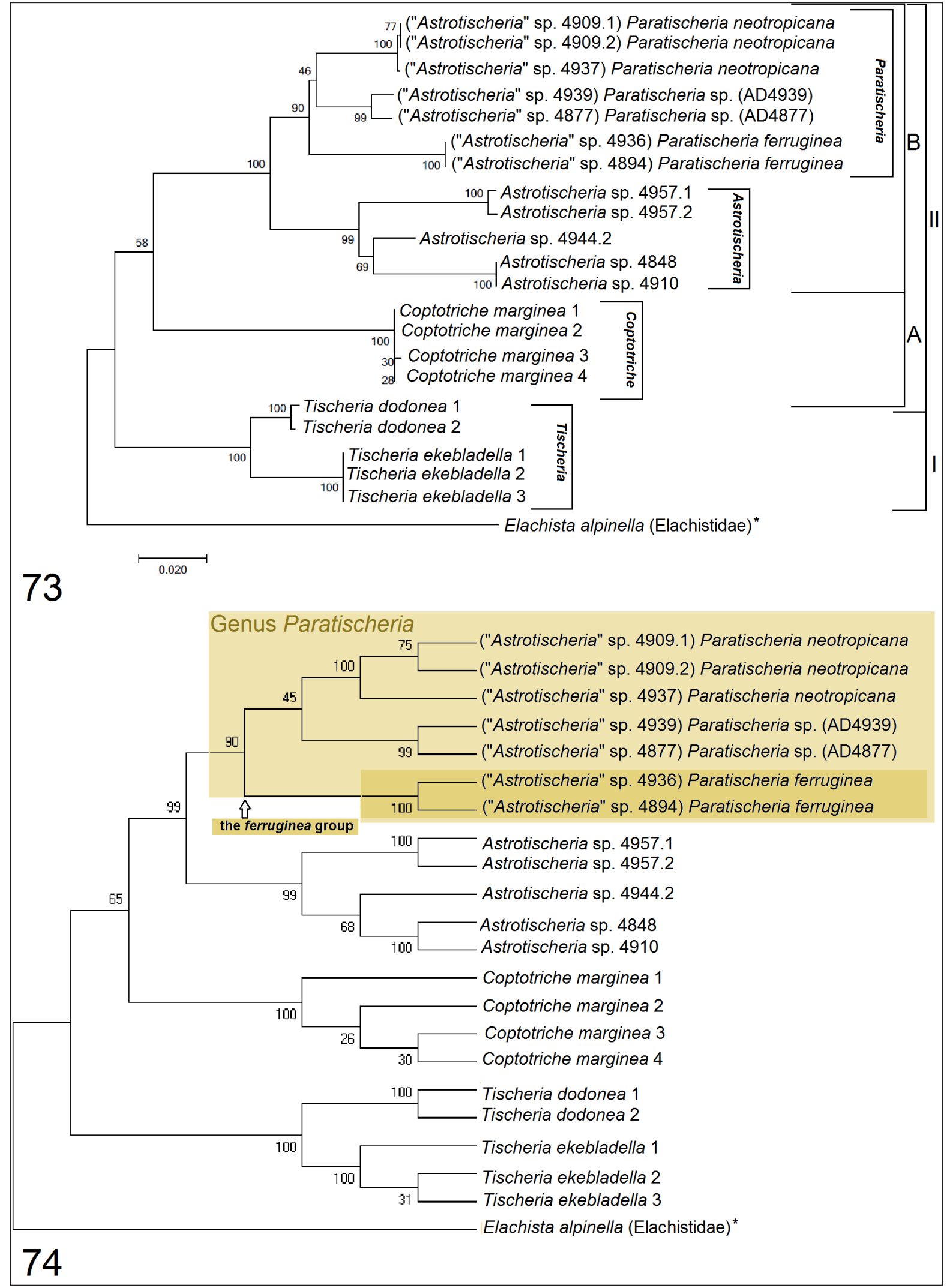

Figs. 73, 74. Molecular phylogeny of Tischeriidae: 73 - neighbour-joining tree for specimens of Tischeriidae with Elachista alpinella (GU248257.1) as outgroup; bootstrap values are shown above; 74 - same, other presentation 
long slender setae. Anterior and posterior apophyses very long and slender (Fig. 29). Additionally there are three rod-like and plate-like projections (of possibly modified 8th and 9th sternites) collectively referred to as the prela described by Braun (1972) (Figs. 30, 31). Ductus bursae considerably narrower than corpus bursae, without spines but with a hardened plate (Fig. 30). Corpus bursae membranous, relatively very small (500 $\mu \mathrm{m}$ long, $200 \mu \mathrm{m}$ wide) (Fig. 31), without spines or signum. Ductus spermathaecae with many large coils (Fig. 31).

Bionomics (Figs. 11-25). Host plant: Phenax hirtus (Sw.) Wedd. (Urticaceae) (Fig. 11). Larvae mine in late January-February and OctoberNovember. Leaf-mine as a blotch (at the early stage triangular or distally widely rounded, later very irregular), without frass. Larva pale greenish grey, with pale grey-brown intestine. Pupation inside of the leaf-mine without cocoon; pupa brown (Figs. 20-25). Exit slit on the upper side of the leaf. Adults known from February, March, and December. According to the "Formula of Determining of Abundance and Occurrence of Leaf-miners" (see Diškus \& Stonis 2012: 52-54), P. ferruginea is not a rare species: limited in distribution, but abundant mining in the locality where it has been recorded.

Distribution (Figs. 1, 3). This species occurs in the Ecuadorian Andes in tropical montane and cloud forests at altitudes about 2940$3100 \mathrm{~m}$.

Etymology. The species name is derived from the Latin ferruginea (brown, yellowish brown) in reference to the distinctive yellow beige spot of the forewing and same ferruginous abdomen on underside.

\section{DISCUSSION}

Within the family Tischeriidae, analysis of morphological characters indicates at least four main lineages of a generic rank (Stonis et al., in prep.).

During our molecular studies, partial fragment of the COI gene were amplified in 21 specimens of Tischeriidae resulting in a 577-bp fragment. The sequences have 147 polymorphic nucleotides. 145 nucleotides were found to be parsimony-informative characters. All four lineages indicated by morphological studies were well supported by our molecular data; see the cladogram (NJ tree) in Figs. 73, 74. The NJ tree of Tischeriidae (Fig. 74) has two big clusters: I and II. The cluster I includes species from the genus Tischeria: European T. dodonaea and T. ekebladella. Among these two species, 24 polymorphic nucleotides were detected.

Cluster II is formed of two groups: the first group (A) is represented by Coptotriche (European Coptotriche marginea) and the second group (B) by the species of South American Astrotischeria and Paratischeria. The COI gene sequences of investigated specimens from cluster B indicated 52 polymorphic and 525 conservative nucleotides.

There is a difference between the cladogram published by Diškus, Puplesis (2003b) and our NJ tree (Fig. 74). Previously two clades, Tischeria and Astrotischeria, were shown as sibling (Diškus, Puplesis, 2003); in our NJ tree, the sibling group is Coptotriche and Astrotischeria + Paratischeria; other major cluster presents the genus Tischeria.

Our study has identified several distinct groups which are supported by the COI gene region (it also has shown that this particular gene is suitable for the reconstruction of the Tischeriidae phylogeny). However, more molecular data and further studies are necessary to confirm the detected cladas in our preliminary cladogram.

The conducted specific molecular research provides a theoretical and practical framework for a further use of DNA molecular markers in taxonomy and phylogenetic studies of Tischeriidae.

\section{ACKNOWLEDGEMENTS}

For helpful and frequent discussions on various host plants (not only those which are listed in the current paper) we thank Nixon Cumbicus Torres (Universidad Técnica Particular de Loja, Loja, Ecuador), Arvind Singh (Banaras Hindu University, Varanasi, India); Narayanan Nair Mohanan (Jawaharlal Nehru Tropical Botanic 
Garden and Research Institute, India), José Luis Fernández-Alonso (Universidad de Salamanca, Spain), Theodor C. H. Cole (Universität Heidelberg, Germany), Maximilian Weigend (University of Bonn, Germany), and Franz Starlinger (Federal Research and Training Centre for Forests, Natural Hazards and Landscape, Vienna, Austria).

Further we would like to thank Andrius Remeikis (Nature Research Centre, Lithuania) for providing us with photographs of genitalia and adults of Tischeriidae.

Received 3 January 2017 Accepted 30 March 2017

\section{References}

1. Bjerkander C. Phalaena Ekebladella en ny Nattfáril belkrifven. Kungliga Svenska Vetenskapsakademiens Handlingar. 1795; 16: 58-63. Swedish.

2. Braun AF. Tischeriidae of America North of Mexico (Microlepidoptera). Memoirs of the American Entomological Society. 1972; 28: $1-148$.

3. Diškus A, Puplesis R. Catalogue of the world Nepticuloidea \& Tischerioidea. In: Puplesis R, Diškus A, editors. The Nepticuloidea \& Tischerioidea (Lepidoptera) - a global review, with strategic regional revisions. Kaunas: Lutute Publishers; 2003a. p. 318-436.

4. Diškus A, Puplesis R. Nepticuloidea and Tischerioidea - the world context. In: Puplesis R, Diškus A, editors. The Nepticuloidea \& Tischerioidea (Lepidoptera) - a global review, with strategic regional revisions. Kaunas: Lutute Publishers; 2003b. p. 38-175.

5. Diškus A, Stonis JR. Astrotischeria neotropicana sp. nov. - a leaf-miner on Sida, Malvaceae, currently with the broadest distribution range in the Neotropics (Lepidoptera, Tischeriidae). Zootaxa. 2015; 4039(3): 456-66.

6. Diškus A, Stonis JR. Lietuvos endobiontiniai vabzdžiai. Nepticulidae faunos chorologinè, taksonominè ir trofinè charakteristika [Leafmining insects of Lithuania. The Nepticulidae (Lepidoptera): taxonomy, chorological composition and trophic relationships]. Kaunas: Lutute Publishers. 2012; 220 p. Lithuanian.

7. Diškus A, Stonis JR. Tischeria species (Insecta, Lepidoptera, Tischeriidae) in Lithuania. Acta Zoologica Lituanica. 2006; 16(3): 215-20.

8. Diškus A, Stonis JR, Cumbicus Torres N. First discovery of leaf-mining Nepticulidae and Tischeriidae (Lepidoptera) associated with the Chilean endemic genus Podanthus Lag. (Asteraceae) as a host-plant. In: Stonis JR, Hill SR, Diškus A, Auškalnis T, editors. Selected abstracts and papers of the First Baltic International Conference on Field Entomology and Faunistics. Vilnius: Edukologija Publishers; 2014; p. 30-31.

9. Folmer O, Black M, Hoeh W, Lutz R, Vrijenhoek R. DNA primers for amplification of mitochondrial cytochrome $\mathrm{c}$ oxidase subnit I from diverse metazoan invertebrates. Molecular Marine Biology and Biotechnology. 1994; 3: 294-7.

10. Ghesquière J. Catalogues raisonnés de la Faune entomologique du Congo belge. Lépidoptères Microlépidoptères (première partie). Annalen van het Koninklijk Museum van Belgisch Congo, nieuwe reeks in 40 [zoologische weten] ser III (II). 1940; 7(1): 1-20. French.

11. Hua HG, Cai TJ. New records of a genus and a species of the family Tischeriidae (Lepidoptera) from China. Entomotaxonomia. 2009; 31(1): 58-61.

12. Haworth AH. Lepidoptera Britannica. 1828; 4: 512-609. J. Murray, London.

13. Hebert PDN, Cywinska A, Ball SL, DeWaard JR. Biological identifications through DNA barcodes. Proc. R. Soc. Lond. 2003a; B 270, 313-22.

14. Hebert PDN, Ratnasingham S, DeWaard JR. Barcoding animal life: Cytochrome $\mathrm{c}$ oxidase subunit 1 divergences among closely related 
species. Proc R Soc Lond B Biol Sci. 2003b; 270: 596-9.

15. Kobayashi S, Sato H, Hirano N, Yamada K, Hirowatari T. Two new and two newly recorded species of the family Tischeriidae (Lepidoptera) from Japan, with descriptions of the life history. ZooKeys. 2016; 601: 127-51.

16. Kumar S, Stecher G, Tamura K. MEGA7: Molecular Evolutionary Genetics Analysis version 7.0. Molecular Biology and Evolution. 2015.

17. Landry B, Roque-Albelo L. First report of Tischeriidae (Lepidoptera) on the Galapagos Islands, Ecuador, with descriptions of two new endemic species. Revue suisse de Zoologie. 2004; 111(3): 599-609.

18. Lees DC, Stonis JR. The first record of Tischeriidae (Insecta: Lepidoptera) from Madagascar, with description of Coptotriche alavelona sp. n. and an update distributional checklist of Afrotropical Tischeriidae. Zootaxa. 2007; 1645: 35-45.

19. Mey W. Nepticulidae (Lepidoptera, Nepticuloidea). In: Mey W, editor. The Lepidoptera of the Brandberg Massif in Namibia. Esperiana Memoir. 2004; 1: 27-38.

20. Mey W. Two new species of Tischeriidae from East Africa (Lepidoptera, Tischerioidea). Esperiana Memoir. 2010; 5: 337-40.

21. Navickaitė A, Diškus A, Stonis JR, Dobrynina V. Taxonomic catalogue of the world Nepticuloidea and Tischerioidea (Lepidoptera) described by members of the Biosystematics Research Group (Lithuania) up to 2009. Acta Zoologica Lituanica. 2011; 21(2): 113-32.

22. Nieukerken EJ van. Order Lepidoptera, family Tischeriidae. Arthropod fauna of the UAE. 2010; 3: 515-8.

23. Puplesis R, Diškus A. The Nepticuloidea \& Tischerioidea (Lepidoptera) - a global review, with strategic regional revisions. Kaunas: Lututė Publishers; 2003. 512 p.

24. Puplesis R, Diškus A. Checklist of African Tischeriidae (Insecta: Lepidoptera) with a re- description of the formerly neglected Tischeria urticicolella from Equatorial Africa. Zoological Science. 2005, 22(9): 1051-5. http://dx.doi. org/10.2108/zsj.22.1051

25. Puplesis R, Diškus A, Mey W. Tischeriidae. In: Mey W, editor. The Lepidoptera of the Brandberg Massif in Namibia. Esperiana Memoir. 2004; 1: 39-51. Berlin.

26. Stainton HT. General observations on the genus Tischeria. The Natural History of the Tineina. 1858; 3(1): 226-65.

27. Saitou N, Nei M. The neighbor-joining method: a new method for reconstructing phylogenetic trees. Molecular Biology and Evolution. 1987; 4(4): 406-25.

28. Stonis JR, Diškus A. Distribution of Tischeria gouaniae sp. n. from the tropical forest of Belize - an exotic new addition to the American fauna of Tischeria (Insecta: Lepidoptera: Tischeriidae). Zoological Science. 2007; 24(12): 1286-91.

29. Stonis JR, Diškus A. Checklist of American Coptotriche (Insecta: Lepidoptera: Tischeriidae) with descriptions of two new species from the tropical forest of Belize (Central America). Zoological Science. 2008; 25(1): 99-106.

30. Stonis JR, Diškus A, Remeikis A, Cumbicus Torres N. First description of leaf-mining Nepticulidae and Tischeriidae (Insecta, Lepidoptera) feeding on the Chilean endemic plant genus Podanthus Lag. (Asteraceae). Zootaxa. 2016: 4061(2): 119-30.

31. Stonis JR, Diškus A, Remeikis A, Monro AK. The mystery of the tiny Urticaceae-feeders: documentation of the first leaf-mining Nepticulidae (Lepidoptera) species from equatorial America associated with Phenax, Boehmeria and Pilea. Biologija. 2017 (submitted/ accepted).

32. Stonis JR, Diškus A, Remeikis A, Navickaitè A. Study methods of Nepticulidae: micro-mounts of genitalia structures. In: Stonis JR, Hill SR, Diškus A, Auškalnis T, editors. Selected abstracts and papers of the First Baltic International Conference on Field Entomology and 
Faunistics. Vilnius: Edukologija Publishers; 2014. p. 32-5.

33. Stonis JR, Diškus A, Rocienè A, Sruoga V, Davis DR. New and little known Coptotriche and Tischeria species (Lepidoptera: Tischeriidae) from Primorskiy Kray, Russian Far East. Zootaxa. 2014; 3884(2): 141-55.

34. Stonis JR, Diškus A, Sruoga V. Redescription of Coptotriche pulverea (Walsingham) - an unusual species of the American Tischeriidae fauna (Insecta: Lepidoptera). Acta Zoologica Lituanica. 2008; 18(3): 169-73.

35. Thompson JD, Higgins DG, Gibson TJ. Clustal $\mathrm{W}$ : improving the sensitivity of progressive multiple sequence alignment through sequence weighting, position-specific gap penalties and weight matrix choice. Nucleic Acids Res. 1994; 22: 4673-80.

36. Wu Z-Y, Monro AK, Milne IR, Wang H, Yi T-S, Liu J, Li D-Z. Molecular phylogeny of the neetle family (Urticaceae) inferred from multiple loci of three genomes and extensive generic sampling. Molecular Phylogenetics and Evolution. 2013; 69: 814-27.

\section{Jonas Rimantas Stonis, Arūnas Diškus,} Brigita Paulavičiūtè, Alex K. Monro

\section{URTICACEAE AUGALUS MINUOJANTYS TISCHERIIDAE: DVI NAUJOS MOKSLUI RŪŠYS IR NAUJA PARATISCHERIA GENTIS}

\section{Santrauka}

Šiame straipsnyje pirmą kartą publikuojami duomenys apie Urticaceae šeimos augalus minuojančius Tischeriidae Pietų Amerikoje. Aprašoma nauja Paratischeria gentis ir dvi naujos mokslui rūšys: Paratischeria fasciata (aptikta Bolivijoje) ir P. ferruginea (aptikta Ekvadore). Šios dvi rūšys kartu su pusiaujo Afrikoje paplitusia P. urticicolella (Ghesquière) (comb. nov.) pirmą kartą išskiriamos $\dot{i}$ atskirą Paratischeria genties rūšių grupę, kuriai būdingas pakitęs patino anellus ir dilgèlinių augalų (Phenax, Fleurya) minavimas.

Raktažodžiai: Andai, nauja gentis, nauja rūšis, Paratischeria, Pietų Amerika, Phenax Wedd., Tischeriidae, Urticaceae 